\title{
MARKETING MIX ANALYSIS ON CONSUMER BUYING INTERESTS OF MORINGA LEAF NOODLE PRODUCTS IN MALANG CITY
}

\author{
Hidayat Savitri Winawati ${ }^{*}$, Student \\ Wisnujati Nugrahini Susantinah, Rahayu M.J.H. Sri, Lecturers \\ Postgraduate Program of Agribusiness, Faculty of Agriculture, Wijaya Kusuma University, \\ Surabaya, Indonesia \\ *Email: hai wina@yahoo.com
}

\begin{abstract}
Moringa leaves are horticultural plants that thrive in Indonesia, especially in Malang city. To increase the value added, moringa leaves are processed into moringa leaf noodle so that they have high business prospects. Moringa leaf noodle are rich in benefits for the body because they contain vitamins $\mathrm{A}, \mathrm{C}$, calcium, flavonoids and phenols. Through marketing mix strategy, it is expected that manufacturers can increase consumer buying interest in moringa leaf noodle and products can compete in the market. This study aims to analyze the influence of marketing mix consisting of product variables $\left(X_{1}\right)$, price $\left(X_{2}\right)$, distribution $\left(X_{3}\right)$ and promotion $\left(X_{4}\right)$ simultaneously and partially to the consumer buying interest of moringa leaf noodle $(Y)$ in Malang city. This research uses a quantitative approach. The subjects of this study were 50 respondents who purchased moringa leaf noodle in Malang city. The analysis method used is multiple linear regression, with the help of statistical package for social science (SPSS) 25.0 for the windows program. The results of the study obtained the equation of regression formed is $Y=2.292+0.72 X_{1}+0.324 X_{2}-0.008 X_{3}+0.383 X_{4}$. It is concluded that product variables, prices, distribution and promotion simultaneously affect the buying interest of moringa leaf noodle. Product variables and distribution have no partial effect on the buying interest of moringa leaf noodle. Prices and promotions variables partially affect moringa leaf noodle.
\end{abstract}

\section{KEY WORDS}

Analysis, marketing mix, moringa leaf noodle.

Indonesia has many potential horticultural plants that are useful, one of which is moringa plants. Moringa oleifera is a plant that thrives in Indonesia and has the potential to be developed. Moringa leaves contain nutrients that are beneficial to the body. So far, Indonesian people consume moringa leaves as vegetables and livestock experts. Various forms of product diversification made from moringa leaves are moringa leaf tea, moringa leaf chips and moringa leaf noodle. Products that have been widely circulated are moringa leaf herbal tea and moringa leaf chips containing antioxidants, flavonoids, vitamin $\mathrm{C}$ and bioactive compounds. Abroad, moringa leaves are even processed into cosmetic ingredients, because moringa leaves are rich in antioxidants that can regenerate skin cells. Noodle are basically foods that are low in fiber, but get better with the addition of moringa leaves as a source of fiber (Ganga et al., 2019). From the results of the study, moringa leaf crispy noodle showed the content of vitamin $\mathrm{A}, \mathrm{C}$, calcium and bioactive components namely flavonoids and phenols (Adi et al., 2019). Consumers' desire for a food product is not only delicious taste, affordable price but also safe and healthy.

The small and medium micro enterprises (UMKM) play an important and strategic role in national economic development, including UMKM in the food sector. The growth of UMKM is an economic potential that must be considered by various parties so that UMKM can continue to compete in the national and international markets, contribute to the economic sector and be able to absorb labor. Moringa leaf noodle are produced by one of the UMKM in Malang city. The number of UMKM engaged in the field of similar food processing makes manufacturers should always be able to increase consumer buying interest. A consumer's buying interest is a response to an object that hints at a consumer's interest or desire to buy 
a product. In addition to increasing the consumer's buying interest, it is expected that products can continue to compete in the market, so that it can continue to benefit manufacturers. Therefore, manufacturers need to understand and learn how the surrounding environment can affect consumer buying interests and pay attention to appropriate marketing mix strategies. Marketing mix in question is covering products, prices, promotions and distribution, or can be referred to as $4 \mathrm{P}$.

Moringa leaf noodle products have been circulating, but it is still quiet enthusiasts. This is because people are still lay with moringa leaf noodle. Although the public has known the benefits of moringa leaves, but for moringa leaf noodle products still not many know. The right marketing strategy can keep consumers interested and buy products, can even refer products to others. In some studies that have been done, it is stated that marketing methods marketing mix has a significant and partial effect on consumer buying interests. Based on this, researchers analyzed the influence of marketing mix conducted including products, prices, distribution and promotion of the interest in buying moringa leaf noodle products, simultaneously and partially so that a suitable marketing strategy is obtained for moringa leaf noodle products.

\section{LITERATURE REVIEW}

According to Wahyuni (2013) moringa plants contain vitamins A, B1, B2, and C. In addition moringa also contains more than 90 nutrients called the best natural antioxidants. Has the best source of fiber, betacarotine content 4 times greater than carrots there are also omega 3 oils and chlorophyll. One of the most prominent of the content of moringa plants is antioxidants especially on the part of the leaves that contain the highest antioxidants. Antioxidants found in moringa leaves include tannins, steroids, triterpenoids, flavonoids, saponins, antarquinons, and alkaloids (Kasolo et al, 2010, in Hardiyanthi 2015). The blessing of abortion that moringa was given the name "Miracle Tree" or "Tree of Life". Internationally this plant has been promoted by various organizations such as the WHO (World Health Organization), National Geographic, National Institute of Health, and others to address malnutrition in poor countries (Krisnadi, 2010). In the field of food, moringa plant has been used to address malnutrition, especially for toddlers and breastfeeding mothers. The leaves of the moringa plant can be consumed fresh, cooked, or stored in the form of flour for a few months without cooling and without going lose its nutritional value. Processing of moringa leaves into flour will be able to increase the calorific value of, the content of protein, calcium, iron and vitamin $\mathrm{A}$. This is due at the time of processing moringa leaves into flour will happen reduction of the water content contained in the leaves of moringa (Dewi et al., 2016).

Tjiptono (2011) stated that marketing strategy is a plan to be followed by the manager marketing. The plan of action based on the situation analysis and objectives of the company, is also the way to the achievement of these goals. One of planning the marketing strategy is to use the concept of the marketing mix. The marketing mix is all the factors that can be controlled by a manager marketing in order to affect consumer demand for the product. The marketing mix has an important role in influencing consumers to buy the products or services it offers, similarly for the success of a marketing marketing products or services. According to Mc. Carthy in Kotler and Armstrong (2015) in the marketing mix there is a set of marketing tools is known by the marketing mix 4P, i.e., product (product), price (price), place (the place or channel of distribution), and promotion (the promotion).

According to Kasali (2010) a product is anything whether it be goods, services, or ideas offered to the market to be obtained, used, or consumed, which can meet the needs of consumers. The components of the product in the marketing mix (4P) may include the type of product, quality, product design, product capabilities, brands, packaging, sizes, services, warranties, and return (Kotler and Keller, 2016). According to Monroe in Sukotjo (2010), the price is the sacrifice economical to do by the consumer to be able to obtain products marketed by the company. Prices should be competitive and contains the advantage (Lin, 2011). According To Ong and Sugiharto (2013) the indicator of the price of, among others, is a price that is affordable by the purchasing power of consumers, price competitive with the 
prices of other products and suitability price with quality products. Products can reach customers through the distribution channel. Distribution channel is a set of companies or individuals who participate in the flow of the product from the manufacturer up to the end user or consumers, for example through online motorcycle taxi, courier, and delivery services of goods (Lin, 2011). The components of the place or distribution in the marketing mix (4P) can covers distribution network, range, location, supply, and transportation (Kotler and Keller, 2016). According to Muanas and Suhermin (2014), promotion is a media to introduce a products goods and services that are new or strengthen the brand image of a product that has been there before. Sometimes the promotion is aimed at getting new customers and retain existing customers. Components of promotion in the marketing mix (4P) may include promotion of sales, ad, the sales force, public relations, and direct sales (Kotler and Keller, 2016). According to Cronin et al. (Widyaningrum, 2017) buying interest is the behavior of customers where customers respond positively to the quality of the products or services of a company and intend to consume return the product of the company. According to Akmal (2014) buying interest can be identified through some of the indicators, that are interested to try, consider to buy, want to have a product and want to know the product.

Formulation of the problem and the purpose of this study is to analyze the aspects of the marketing mix in consumer buying interest for moringa leaf noodle products. So the hypothesis in this study is:

$\mathrm{H}_{1}$ : Expected variable product, price, distribution and promotion in the marketing mix, have a simultaneous effect on consumer buying interest of moringa leaf noodle.

$\mathrm{H}_{2}$ : Expected a variable product in the marketing mix, have a partial effect on consumer buying interest of moringa leaf noodle.

$\mathrm{H}_{3}$ : Expected price variables in the marketing mix, have a partial effect on consumer buying interest of moringa leaf noodle.

$\mathrm{H}_{4}$ : Expected variable distribution in the marketing mix, have a partial effect on consumer buying interest of moringa leaf noodle.

$\mathrm{H}_{5}$ : Expected variable promotion in the marketing mix, have a partial effect on consumer buying interest of moringa leaf noodle.

\section{METHODS OF RESEARCH}

This study uses a quantitative approach, because it uses numerical data start to data collection, interpretation of data, as well as the appearance of the result. Further described based on the theory, the general theory and observation to test the validity of the the applicability of the theory so that it can be drawn a conclusion that will be elaborated in a descriptive to answer the problem formulation. The number of respondents in this study were as many as 50 people, namely the consumer of moringa leaf noodle make a purchase in the Malang city. This research uses 4 independent variables and 1 dependent variable. The independent variable consists of the product $\left(\mathrm{X}_{1}\right)$, price $\left(\mathrm{X}_{2}\right)$, distribution $\left(\mathrm{X}_{3}\right)$, and promotion $\left(\mathrm{X}_{4}\right)$. The dependent variable is consumer buying interest $(\mathrm{Y})$. Data collection method of this research is through the questionnaire method of data collection that is done by dividing the list of statements in writing and systematic. This study uses a Likert scale to determine the influence of product, price, distribution, and promotion to consumer buying interest.

After the data obtained from the Likert scale, and the data is then processed using the Statistical Package for Social Sciences (SPSS) 25.0 for windows. Data were analyzed using validity and reliability test to test the valid and reliable a list of questions on the questionnaire used in this study. Further testing deviation of classic assumption, which consists of normality test, multicollinearity and heteroscedasticity. Normality test is a test whether the data collected normally distributed or not. Testing multicollinearity is used to see whether a model used there is a correlation (strong relationship) between the independent variables with the dependent variable. Test the assumption of heteroscedasticity aims to test the linear regression model is a dissimilarity a variant of the residual one to the residual of the observation of others. Furthermore, testing the hypothesis, which consists of the simultaneous test ( $F$ test), partial test ( $T$ test) and test the coefficient of determination $\left(R^{2}\right)$. 
Simultaneous test ( $F$ test) was used to determine the effect of variable the independent on the dependent variable simultaneously. Partial test ( $T$ test) aims to test the influence of independent variables (product, price, distribution and promotion) on the dependent variable partial. Test the coefficient of determination $\left(R^{2}\right)$ is used to measure how much the ability of independent variables in explaining the dependent variable. One of the methods to determine the relationship between two or more variables in this study is multiple linear regression analysis method.

In this study, because it uses multiple linear regression analysis, then the equation is formulated following:

$$
Y=\alpha+\beta_{1} \cdot X_{1}+\beta_{2} \cdot X_{2}+\beta_{3} \cdot X_{3}+\beta_{4} \cdot X_{4}+e
$$

Where: $Y$ is consumer buying interest (dependent variable); $\alpha$ is a constant; $\beta_{1}, \beta_{2}, \beta_{3}$ and $\beta_{4}$ are the coefficients of regression of the independent variable; $X_{1}$ is variable products of moringa leaf noodle (independent variable); $X_{2}$ is variable prices of moringa leaf noodle (independent variable); $X_{3}$ is variable distribution of moringa leaf noodle (independent variable); $X_{4}$ is variable promotion of moringa leaf noodle (independent variable); $e$ is a error factor.

\section{RESULTS AND DISCUSSION}

The respondents in this study amounted to 50 people. The respondent is taken from the consumer make a purchase direct to the location of the sales of moringa leaf noodle in the Malang city. Selected respondents are respondents who have never made a purchase directly to the site sales, because some consumers made a purchase by online. The characteristics of research subjects can be seen in the following table:

Table 1 - Subject Characteristics by Age

\begin{tabular}{|l|l|l|}
\hline Age & Number of Respondents & Percentage (\%) \\
\hline $19-29$ & 4 & 8 \\
\hline $30-40$ & 26 & 52 \\
\hline $41-50$ & 8 & 16 \\
\hline$>50$ & 12 & 24 \\
\hline Total & 50 & 100 \\
\hline
\end{tabular}

Source: Data analysis, 2021.

Based on table 1, it can be seen that the consumer mostly of moringa leaf noodle in the Malang city are the consumers with the age of 30-40 years. This is because in the age range of 30-40 years, consumers generally more open and critical of product information. This is followed by consumers aged above 50 years and $41-50$ years; this is because at this age consumers tend to choose foods that are healthy and safe from chemicals. Consumer with age 19-29 years is the youngest; this is because the consumer does not have the attitude or intention specific to the consumption of moringa leaf noodle, so the motivation in buying a product is not necessarily to be consumed by the respondents themselves.

Table 2 - Subject Characteristics by Gender

\begin{tabular}{|l|l|l|}
\hline Gender & Number of Respondents & Percentage (\%) \\
\hline Male & 13 & 26 \\
\hline Female & 37 & 74 \\
\hline Total & 50 & 100 \\
\hline
\end{tabular}

Source: Data analysis, 2021. 
Based on table 2 , the data can be analyzed that $74 \%$ of female respondents are more likely to easily affected in the purchase or consume products of moringa leaf noodle. Female consumers are the most easily influenced and carried away the flow of information related culinary products. Rest as much as $26 \%$ of respondents were male. It can be analyzed that the male respondents generally buy out of necessity, not because of desire. Male respondents also tend to not be easily influenced and carried away by the current information such as the female respondents.

Based on table 3 , information about the education of the respondents need to be aware, due to educational factors influencing consumer buying interest in noodle products of moringa leaf noodle. It can be concluded, that the factor of education is quite high and good, it will produce understanding and perception against something. On the respondents with the highest education is high enough, will produce a thought that is widespread in receive and respond to information products.

Table 3 - Subject Characteristics by Education

\begin{tabular}{|l|l|l|}
\hline Education & Number of Respondents & Percentage (\%) \\
\hline Senior High & 6 & 12 \\
\hline Associate's Degree & 11 & 22 \\
\hline Bachelor & 31 & 62 \\
\hline Other & 2 & 4 \\
\hline Total & 50 & 100 \\
\hline
\end{tabular}

Source: Data analysis, 2021.

In this research used multiple linear regression analysis that aims to prove the hypothesis regarding the influence of the variables of product, price, distribution and promotion is partially or simultaneously on buying interest of moringa leaf noodle. The results of data processing using SPSS 25.0 for windows is:

1. Model regression equation can be written in the form of the equation of the regression standardized is following:

$$
Y=2,292+0,72 X_{1}+0,324 X_{2}-0,008 X_{3}+0,383 X_{4}
$$

The regression equation can be explained that:

a. The regression coefficient of variable products has a positive value. This suggests that each additional the value of $X_{1}$ will add the $Y$ value of 0,72 . It is concluded that the increase in variable product will be increasing buying interest of moringa leaf noodle.

b. The regression coefficient of the variable price has a positive value. This suggests that each additional the value of $X_{2}$ will add the value of $Y$ at 0,324 . It is concluded that the increase in the price variable will increasing buying interest of moringa leaf noodle.

c. The regression coefficient of the variable distribution has a negative value. This shows that every the addition of the value of $X_{3}$ will lower the value of $Y$ at are 0,008 . It is concluded that the increase in the variable the distribution will lose buying interest of the moringa leaf noodle.

d. The regression coefficient of the variable promotion has a positive value. This suggests that each additional the value of $X_{4}$ will add the value of $Y$ at 0,383 . It is concluded that the increase in the variable promotion will be increase buying interest of moringa leaf noodle.

e. The constant of 2,292 that if $X_{1}, X_{2}, X_{3}$, and $X_{4}=0$, then the value of $Y=2,292$.

2. Furthermore, the performed $F$ test to test the variable independents consisting of product, price, distribution and promotion effect together against to buying interest of moringa leaf noodle. The basis of decision-making (Ghozali, 2005):

a. Compare the $F$ count and $F$ table: 
If $\mathrm{F}$ count $<\mathrm{F}$ table, then $\mathrm{H}_{0}$ is accepted and $\mathrm{H}_{1}$ is rejected;

If $\mathrm{F}$ count $>\mathrm{F}$ table, then $\mathrm{H}_{0}$ is rejected and $\mathrm{H}_{1}$ is accepted.

b. Use the number of probability significance:

If the probability of significance $>0.05$, then $\mathrm{H}_{0}$ is accepted and $\mathrm{H}_{1}$ is rejected;

If the probability of significance $<0.05$, then $\mathrm{H}_{0}$ is rejected and $\mathrm{H}_{1}$ is accepted.

From table 4 , the result show that $F$ count $>F$ table, which is $7,831>2,58$. Sig $<0,05$, which is $0,000<0,05$. It means that the variable of product $\left(X_{1}\right)$, price $\left(X_{2}\right)$, distribution $\left(X_{3}\right)$ and promotion $\left(\mathrm{X}_{4}\right)$ effect together or simultaneously on buying interest of moringa leaf noodle $(Y)$. So the first hypothesis is proven true, that the independent variables of the marketing mix influence simultaneously on buying interest of moringa leaf noodle in Malang city.

Table 4 - The Results of the F Test

\begin{tabular}{|c|c|c|c|c|}
\hline Variable & F count & F table & Sig. & $\mathrm{R}^{2}$ \\
\hline Consumer buying interest $(\mathrm{Y})$ & \multirow{4}{*}{7,831} & \multirow{4}{*}{2,58} & \multirow{4}{*}{0,000} & \multirow{4}{*}{0,41} \\
\hline Product $\left(\mathrm{X}_{1}\right)$ & & & & \\
\hline Price $\left(X_{2}\right)$ & & & & \\
\hline $\begin{array}{l}\text { Place/ Distribution }\left(\mathrm{X}_{3}\right) \\
\text { Promotion }\left(\mathrm{X}_{4}\right)\end{array}$ & & & & \\
\hline
\end{tabular}

Source: Data analysis, 2021.

3. The $\mathrm{T}$ test was used to test the influence of independent variables (product, price, distribution and promotion) on the dependent variable (buying interest of moringa leaf noodle) partially. The $T$ test can be analyzed by taking a variable for testing with a view of the column of significance on the coefficient table. Have a partial effect between the independent variables with the dependent variable if the $T$ count or the significance $<0.05$. Have no partial effect between the independent variables with the dependent variable if $T$ count or significance $>0,05$. From the calculation using SPSS 25.0 following results:

From table 5 , the results show that:

a. The results of $T$ count $0,842<T$ table value 2,015 and the results of the significance test with a probability value $0,404>0,05$. Which means that the product variable in the marketing mix, have no partial effect on buying interest of moringa leaf noodle. It can be concluded that the second hypothesis which states that the product variable in the marketing mix, have a partial effect on consumer buying interest of moringa leaf noodle was rejected. Some of the causes of this happens because too many products that are circulating in the Malang city so consumers get bored. This can be overcome by immediately expanding sales to the outer area of Malang city. Respondents data also show that the product of moringa leaf noodle still needs a lot of improvement from the component side of the product.

b. The results of $T$ count 2,153 $<T$ table value 2,015 and the results of the significance test with a probability value $0,037>0,05$. Which means that the price variable in the marketing mix, have a partial effect on buying interest of moringa leaf noodle. It can be concluded that the third hypothesis which states that the price variable in the marketing mix, have a partial effect on consumer buying interest of moringa leaf noodle was accepted. Results data of the respondents shows that the sacrifice of the material that has issued the consumer in accordance with the benefits of moringa leaf noodle. With prices that compete with similar products, moringa leaf noodle have equal opportunities with similar products.

c. The results of T count $-0,068<\mathrm{T}$ table value 2,015 and the results of the significance test with a probability value $0,946>0,05$. Which means that the distribution variable in the marketing mix, have no partial effect on buying interest of moringa leaf noodle. It can be concluded that the fourth hypothesis which states that the distribution variable in the marketing mix, have a partial effect on consumer buying interest of moringa leaf noodle was rejected. Of respondent data have been processed, it can be concluded that consumers are still difficult to reach and less comfortable with the place of sale of the product, so that it can lose buying interest of moringa leaf noodle. This can be overcome by way of establishing 
wider cooperation with some of the stores or the agents by the food which is widely spread in the Malang city.

d. The results of $T$ count $3,863<T$ table value 2,015 and the results of the significance test with a probability value $0,000>0,05$. Which means that the promotion variable in the marketing mix, have a partial effect on buying interest of moringa leaf noodle. It can be concluded that the fifth hypothesis which states that the promotion variable in the marketing mix, have a partial effect on consumer buying interest of moringa leaf noodle was accepted. Results data of the respondents indicated that promotional activities have been conducted by the manufacturer is assessed simply can raise the interest of consumers to buy. The promotion has been done so far is marketing through the digital channel or social media.

Table 5 - The Results of the T Test

\begin{tabular}{|l|l|l|l|l|}
\hline Variable & Beta & T count & T table & Sig. \\
\hline Product $\left(\mathrm{X}_{1}\right)$ & 0.072 & 0.842 & 2,015 & 0.404 \\
\hline Price $\left(\mathrm{X}_{2}\right)$ & 0.324 & 2.153 & 2,015 & 0.037 \\
\hline Place/ Distribution $\left(\mathrm{X}_{3}\right)$ & -0.008 & -0.068 & 2,015 & 0.946 \\
\hline Promotion $\left(\mathrm{X}_{4}\right)$ & 0.383 & 3.863 & 2,015 & 0 \\
\hline
\end{tabular}

Source: Data analysis, 2021

4. On this research, the coefficient of determination used to be able to analyze how much the independent variables have an influence on the dependent variable. The results of the calculation of the regression in SPSS 25.0 known the value of the coefficient of determination ( $R$ square) is 0,410 . This means $41,0 \%$ of consumers interest buying of moringa leaf noodle can be explained by the variables of product, price, distribution and promotion, while the rest of $59,0 \%$ of consumers buying interest of moringa leaf noodle influenced by other variables that are not included in this research.

\section{CONCLUSION}

Overall, moringa leaf noodle can be accepted by consumers in the Malang city. Now a day, a buying interest of the product can be increased through the concept of the marketing mix. Marketing mix has a positive effect on consumer buying interest of moringa leaf noodle. From the research, the variable promotion and price are the most influential. Competitive prices with similar products and exciting promotions online, have been able to attract on consumers buying interest of moringa leaf noodle products. Products and distribution variables still can not make a big impact on consumers interest buying. It can be concluded that still need a lot of improvements on the product and distribution channels, so that the product of moringa leaf noodle can continue and compete in the market.

\section{REFERENCES}

1. Adi, A.C., Rachmah, Q., and Arimbi A.N., 2019. The Acceptance and Nutritional Value of Crispy Noodles Supplemented with Moringa oleifera as a Functional Snack for Children in a Food Insecure Area. Research Report. Universitas Airlangga, Indonesia. Prev. Nutr. Food Sci. 2019; 24(4): 387-392.

2. Armstrong, Kotler. 2015. Marketing an Introducing Prentice Hall twelfth Edition Ganga, M.U., Karthiayani, A., Vasanthi, G., and Baskaran, D. 2019. Study on Development of Fiberenriched Noodles using Moringa Leaves (Moringa olifera). Asian J Dairy Food Res, 38(2):145-149.

3. Dewi, F.K., Suliasih, N. and Gardina, Y. 2016. Pembuatan cookies dengan penambahan tepung daun kelor (Moringa oleifera) pada berbagai suhu pemanggangan. Artikel. http://repository.unpas.ac.id.

4. Ganga, M.U., Karthiayani, A., Vasanthi, G., and Baskaran, D. 2019. Study on Development of Fiberenriched Noodles using Moringa Leaves (Moringa olifera). Asian $\mathrm{J}$ Dairy Food Res, 38(2):145-149. 
5. Ghozali, Imam, 2005, "Aplikasi Analisis Multivariate dengan Program SPSS", Badan Penerbit Universitas Diponegoro, Semarang.

6. Kasali, R. 2010. Modul Kewirausahaan. Yayasan Rumah Perubahan, Jakarta.

7. Kasolo, J.N. 2010. Phytochemicals and Uses of Moringa Oleifera Leaves in Ugandan Rural Communities. Academic Journals, 4(9), 753-757. Diakses dari www.academicjournals.org.

8. Kotler, P. \& Keller, K. L., 2016. Marketing Management. 15th Global ed. Harlow: Perason.

9. Krisnadi, A.D. 2010. Kelor Super Nutrisi. Blora: Pusat Informasi and Pengembangan Tanaman Kelor Indonesia.

10. Lin, S. M., 2011. Marketing Mix 7Pand Performance Assessment of Western Fast Food Industry in Taiwan. African Journal of Business Management, 5(26).

11. Muanas, A., Suhermin. 2014. Pengaruh Produk, Harga and Promosi Terhadap Keputusan Pembelian Mobil Buana Indomobil Trara. Jurnal Ilmu \& Riset Manajemen, 3, $1-17$.

12. Ong, I.A., Sugiharto, S. 2013. Analisa Pengaruh Strategi Diferensiasi, Citra Merek, Kualitas Produk and Harga Terhadap Keputusan Pembelian Pelanggan Di Cincau Station Surabaya. Journal Management Pemasaran, 1, 1-11.

13. Sukotjo, H., 2010. Analisa Marketing Mix 7P terhadap Keputusan Pembelian Produk Klinik Kecantikan Teta di Surabaya. Jurnal Mitra Ekonomi and Manajemen Bisnis, 1(2), pp. 216-228.

14. Tjiptono, F. 2011. Strategi Pemasaran. Yogyakarta: Andi Offset.

15. Wahyuni, S., 2013. Uji Manfaat Daun Kelor (Moringa Olerifera I) untuk Mengobati Penyakit Hepatitis B. Jurnal Kesmadaska Vol 3 (7):100-103.

16. Widyaningrum, N.A. 2017. Dampak Bauran Pemasaran Terhadap Minat Beli Konsumen Pada Produk Crispy Rice Crackers. Performa: Jurnal Manajemen and Start-Up Bisnis. Vol 1 Nomor 6.

17. Yusuf, Akmal. 2014. Perbedaan Minat Beli Konsumen Dalam Mengkonsumsi Gula Aren Asli and Tidak Asli (Studi Kasus Konsumen Industri Kecil Gula Aren di Kecamatan Rambah). Universitas Pasir Pengaraian. 